\title{
Nursing, Indigenous Health, Water, and Climate Change
}

\author{
Darlene Sanderson $^{1,2}$, Noeman Mirza ${ }^{3,}$ Mona Polacca $^{2,}$ Andrea Kennedy ${ }^{4}$ \& R. Lisa Bourque \\ Bearskin ${ }^{1}$ \\ ${ }^{1}$ School of Nursing, Thompson Rivers University, ${ }^{2}$ Indigenous World Forum on Water and Peace, \\ ${ }^{3}$ Faculty of Nursing, University of Windsor, ${ }^{4}$ School of Nursing and Midwifery, Mount Royal \\ University.
}

Cite as: Sanderson, D., Mirza, N., Polacca, M., Kennedy, A. \& Bourque Bearskin, R.L. (2020). Nursing, Indigenous Health, Water, and Climate Change. Witness: The Canadian Journal of Critical Nursing Discourse, 2(1), 66-83. https://doi.org/ 10.25071/2291-5796.55

\begin{abstract}
Authors' Note
Conflict of interest: As two of this manuscript's co-authors served as guest co-editors, this manuscript underwent double-blind peer review with the final editorial review and approval enacted by the journal's editor, Dr. Cheryl van Daalen -Smith.
\end{abstract}

\begin{abstract}
Nurses have a duty to uphold the right to health. Clean water is vital for health as an inclusive right for all people, yet access is threatened by climate change. Complex impacts of colonization on climate change has resulted in two key problems: lack of clean water access by Indigenous Peoples and marginalization of Indigenous traditional teachings that support water protection. Indigenous teachings of living in harmony with Mother Earth are important contributions to global water policy and health solutions. Indigenous traditional laws on water protection may be understood through Indigenous water declarations. Nurses have an important opportunity to respect traditional teachings noting interconnections of health, water, and climate change to advance health. Water is life.
\end{abstract}

Keywords: Indigenous, traditional knowledge, water, climate change, health, nursing 


\section{Opening Prayer}

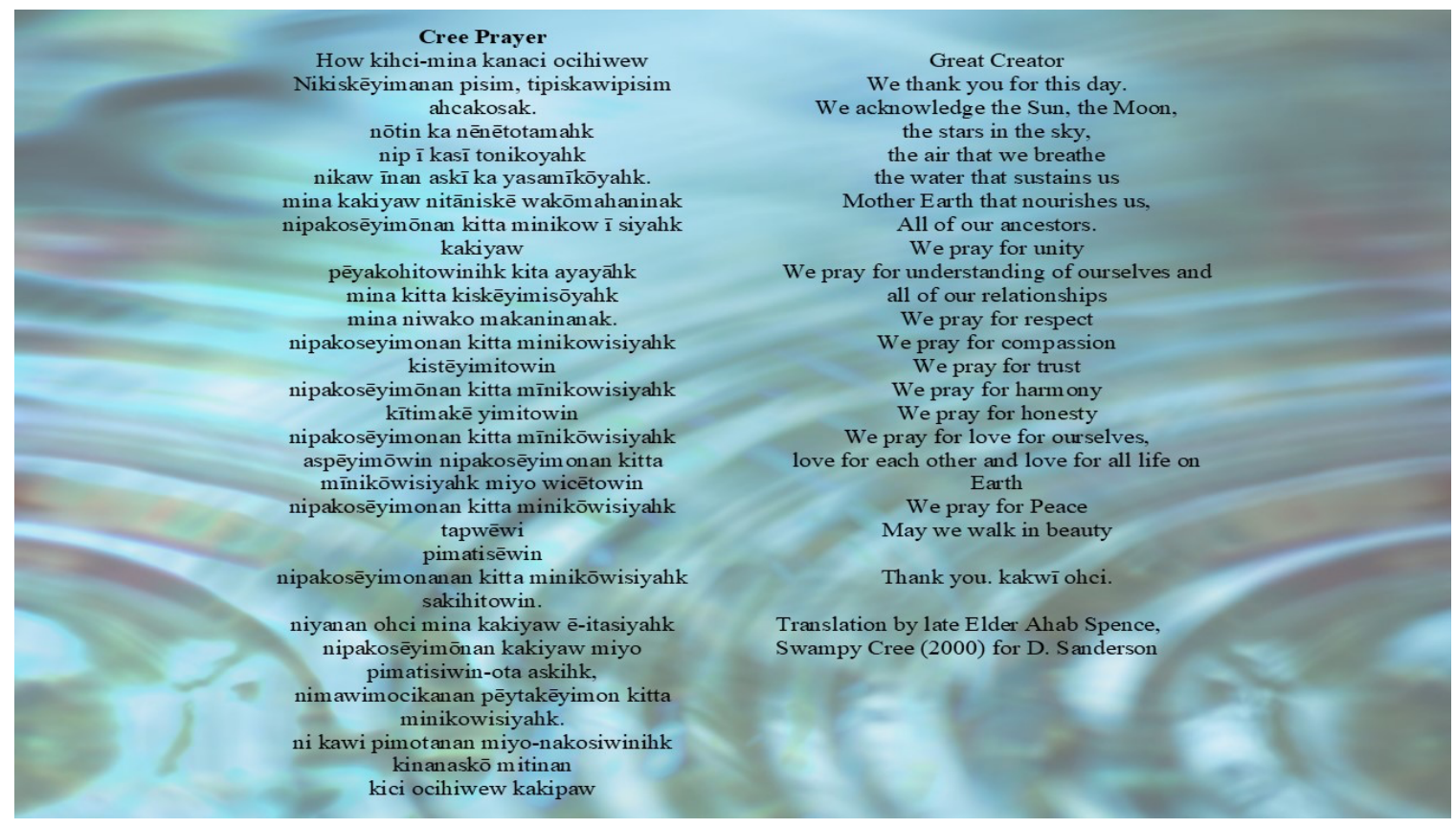

Acknowledgement by Lead Author Darlene Sanderson

I first acknowledge Elders and knowledge keepers who generously guided me over the years and greatly influenced my life's work on water. Mona Polacca (Hopi/Tewa/Havasupai) is a treasured Elder, teacher, mentor, and sister. The late Huirangi Waikerepuru (Aotearoa) was a great warrior and water protector, steeped in culture, peace and dynamic action who taught that ancient laws are needed more than ever. I am grateful to the late Elders Ahab Spence, Peter O'Chiese, Gideon MacKay, and Sandy Beardy (Cree); Elders Sydney Garriock, Reggie Tomatuk (Cree); Hudson and Janet Webster and the late Simon Lucas (Nuu-Chah-Nulth); the late Hohua Tutengaehe, artist TeAturangi Nepia Clamp (Aotearoa); the late TeTika Mataiapo (Rarotonga); Chief Viraleo Boborenvanua and Chief Motarilaveo Hilda Lini (Vanuatu); the late Tomas Alarcon (Aymara, Peru); Tom Goldtooth (Lakota/Dene); Jebra Ram Muchahary (Assam, India); Lucy Mulenkei and Rhoda Rotino (Kenya); Jane Marston, Joan Morris, and the late Simon Charlie (Coast Salish); Dr. Verna Kirkness,
(Cree); Rhona Bowie and Rod Tomma. These people were all instrumental in articulating the interconnectedness of health, education, law, and the environment.

I want to acknowledge the traditional lands and waters that sustained the ancestors and continue to sustain all people. May they continue to share ways to preserve sacred elements with respect and reciprocity. Most of all, I am blessed with my ancestors, my family: giving thanks to all for their prayers, love, and support.

\section{Introduction and Positionality of Authors}

My name is Darlene Sanderson and I am of Cree ancestry (Churchill \& Norway House, Manitoba) on my mother's side and Russian on my father's. I am a mother and a nurse. I am grateful for my education with Cree, Coast Salish, Nuu-Chah-Nulth and Maori Elders for my doctoral work on the meaning of water. I work with Indigenous 
communities on water protection, health, and how traditional laws and teachings about water can help all people. I serve as Co-Secretariat of the Indigenous World Forum on Water and Peace.

My name is Noeman Mirza and I am of Pakistani ancestry. I am a father and a nurse. People of Pakistan share experiences of being colonized. My family has experienced lack of human rights recognition from equity-seeking groups. I work with Tk'emlúps te Secwépemc on their Water Guardians project as part of a Social Sciences and Humanities Research Council (SSHRC) grant and in solidarity of Indigenous practices that promote peace.

My name is Mona Polacca. I am a Hopi/Havasupai/Tewa Elder. I have a Master of Social Work degree. As CoSecretariat of the World Indigenous Forum on Water and Peace, I am an invited speaker on Indigenous Peoples' right to water, social and health issues including Elders. I serve on several United Nations committees for Indigenous peoples; I am a featured author, speaker, and educator on Indigenous Peoples' human rights, aging, mental health, addiction, and violence.

My name is Andrea Kennedy and I am of Settler and Métis ancestry and traditionally adopted by Tsuut'ina and Hawaiian families. I am from RobinsonHuron Treaty territory, and my work is focused on advancing equity and reconciliation in nursing, health, and higher education.

My name is Lisa Bourque Bearskin and I am a Cree Métis member of Beaver Lake Cree Nation. My work stems from my own lived experiences working with healers and helpers to inform Indigenous nursing knowledge and renewed Indigenous health governance systems for community wellness.

Our voices come together to call nurses to respect water as essential to health, to advocate for restoration of Indigenous
Peoples' access to clean water, and to reinforce sovereignty, self-determination, and human rights. Our diverse ways of being, knowing and doing are shaped by our own interpretations of lessons and experiences shared by Elders. Teachings of "living in harmony": to live in balance with the world is to be known as Hopi people; miyo-wîcêhtowin is living in good relationships together as Cree people.

"Water is the giver of all life and without clean water all life will perish." (Assembly of First Nations, n.d.)

\section{Nursing, Indigenous Health, Water, and Climate Change}

\section{Relational Foregrounding}

Clean water is vital for health and is a right for all people (Sandy Beardy, Cree, personal communication, 2001; Gideon MacKay, Cree, personal communication, 2001; Peter O'Chiese, Cree, personal communication, 2001). However, access to renewable clean water is threatened by climate change (Centre of Indigenous Environmental Resources, 2010). The global impact of colonization on climate change, including commodification of water, has resulted in two human rights issues: lack of clean water access by Indigenous Peoples; and, marginalization of Indigenous knowledge systems with water governance (Reading, et al., 2011; United Nations, 2007). Indigenous Peoples see water as sacred and as life itself (Centre of Indigenous Environmental Resources, 2010; McGregor et al., 2018; Sanderson, 2008; Sandford \& Phare, 2011). Through Indigenous Health Nursing, Indigenous and non-Indigenous nurses alike may work together to support Indigenous Peoples' health. Nurses have a responsibility to promote health by advocating clean water for all (Martin \& Vold, 2019; World Health Organization [WHO], 2017a). It is time Canadians take a stand and create space for Indigenous waterway governance structures 
that respect the interrelationships of all beings (Deloria, 1999). Indigenous Peoples' traditional teachings and contributions to global water policy offer compelling solutions towards health for all. This opens an important opportunity for nurses to advocate for access to clean water and build relationships with local knowledge holders to examine global Indigenous water declarations that respect the interconnection of health, water, and climate change. Global water recommendations must be informed by traditional laws and Treaty rights. Nurses can advocate for clean water as a right to health and shared responsibility:

Safe water, sanitation and hygiene at home should not be a privilege of only those who are rich or live in urban centers. These are some of the most basic requirements for human health, and all countries have a responsibility to ensure that everyone can access them (Tedros cited by WHO, 2017).

Nurses are called to examine how health, climate change, and water are interconnected, including root causes, history, and global forces that affect health and wellness. This discussion paper presents an overview of issues and solutions from global Indigenous water declarations that were examined in 2008 and 2015 during gatherings with global Indigenous knowledge holders on Vancouver Island (Coast Salish, Colombia, Cook Islands, Cree, Kenya, Lipan/Apache, Hopi/Tewa/Havasupai, Peru) including coauthors Darlene Sanderson and Elder Mona Polacca. This elevates the need to politically advocate for clean water infrastructure, reduce pollution, and address climate change through traditional laws for a more compassionate relationship with Mother Earth.

\section{Living in Harmony: Indigenous Water Ethic}

Indigenous societies consider water as sacred, protected and respected through ceremony and rights enshrined in nature's laws of Mother Earth (Lavalley, 2006; McGregor et al., 2018; World Peoples' Conference on Climate Change and the Rights of Mother Earth, 2011). Water is identity and water is memory (Indigenous Peoples of the Americas, n.d.; Kogi people, 1992). Mothers carry babies in water before they are born (Mandamin, n.d.; Mona Polacca, Hopi/Tewa/Havasupai, personal communication, 2006), and Indigenous women are "holders of water knowledge" with a special responsibility to protect and hold rights to water (Anderson et al., 2013, p. 11). Water is the most precious of the four elements (Sandy Beardy, Pimicikamak Cree Nation, personal communication, June 8, 2001). Creation stories are based on laws of nature, which are defined in local language and enacted in cultural practices to protect water and life (Huirangi Waikerepuru, Maori, personal communication, 2009; Mona Polacca, Hopi/Tewa/Havasupai, personal communication, 2020).

Since time immemorial, Indigenous ways of being, knowing and doing have developed extensive place-based understanding of living in relationship with water (Mona Polacca, Hopi/Tewa /Havasupai, personal communication, 2010). Local Indigenous teachings of living in harmony extends globally to the interconnection of water as a consecutive worldwide system that connects all of life (TeTika Mataiapo, Rarotonga, personal communication, 2008). Shared traditional ecological knowledge helps us to understand climate change impacts on water and health (Smith \& Sharp, 2012, p. 467). As global citizens, "Nurses for Planetary Health" (Astle et al., 2020), a Nursing community of practice, advocates that the "health of the global citizen is not prioritized at the expense of our planet". This perspective directs nurses to consider micro-to-macro level practices to influence 
planetary wellbeing related to climate change and access to clean water.

\section{Nursing, Water and Climate Change}

Climate change is a priority for

Nursing (Canadian Nurses Association, 2017; International Council of Nurses, 2018) as "the greatest health threat of the 21 st century" (Costello et al., 2009). Climate change is:

... a long-term shift in weather conditions that are identified by changes in temperature, precipitation, winds, and other indicators... human activity has had the single greatest influence. Its two greatest causes are the burning of fossil fuels and deforestation. Both activities result in the release of carbon dioxide into the environment that causes a greenhouse effect that increases temperature (Canadian Public Health Association [CPHA], 2019, p. 6).

Climate change exacerbates an already stressed water world with extreme and unpredictable weather patterns. With melting glaciers, flooding, and droughts, 2.1 billion people do not have access to safe water and more than twice as many live without adequate sanitation (WHO, 2017). Every day, 6,000 children die of waterrelated diseases (UNICEF, 2019). The United Nations (2010) has confirmed water as a human right and furthermore, countries across the globe are recognizing rivers and waterways as having equal rights. (New Zealand Parliament, March 28, 2017).

Climate change and water related health risks include threats to Indigenous ways of life and access to clean water due to "coastal erosion, rising sea level, declining fish stocks, acidification, invasive species, agricultural demands and drought from early snow melt" (CPHA, 2019, p. 6-8). Changes are not isolated; for example, water and land are interconnected as drought increases wildfires which leads to forest decline and reduced carbon absorption (CPHA, 2019, p. $8)$. While climate change impacts everyone, Indigenous Peoples' health is disproportionately affected, and organizations like the Indigenous Environmental Network work hard to have Indigenous perspectives in global climate change dialogues including the Paris Agreement (United Nations, 2015).

It is important for nurses to understand this health issue as a foundation for meaningful local-to-global response for social justice and environmental health. Action includes reducing workplace emissions, educating self and public, lobbying the government to implement the UN Framework Convention on Climate Change, planning patient care to support a healthy planet and preparing for extreme weather (Martin \& Vold, 2019, p. III). A more attuned response is required to address inequities and systemic racism faced by Indigenous Peoples.

Since health is a human right

(Office of the United Nations High Commissioner for Human Rights and WHO, 2008), nurses ought to consider connections between climate change response and the "United Nations Declaration of Rights for Indigenous Peoples" [UNDRIP] (United Nations, 2007). For example, only 1 in 6 First Nations communities in Canada reported access to clean and safe drinking water (Reading et al., 2011). The Government of Canada (2020a) currently reports 61 long term drinking water advisories in effect, with the goal for such advisories to be lifted by March 2021 . Jurisdictional issues continue as nearly 500 Indigenous reserve community drinking water systems need maintenance yet are not recognized as the federal government's legal responsibility (Government of Canada, 2020b).

First Nations are faced with ongoing and emerging health issues including lack of infrastructure for drinkable water, contamination/pollution of water, water- 
borne diseases (Reading et al., 2011), and COVID-19 pandemic (Carling \& Manjani, 2020). Such health challenges, coupled with global erosion of Indigenous Peoples' rights and identity, are rooted in colonial dispossession of lands, territories, and resources (United Nations, 2007, p. 2).

\section{Colonial Harms}

\section{Doctrine of Discovery}

European colonists, guided by Papal Bulls (public decree by the Pope) and the Doctrine of Discovery asserted that lands were terra nullius (empty unless used in European ways), and thereby justified colonists to lay claim to Indigenous lands (Miller, 2015). Lasting legal application on a worldwide scale includes interpretation of Canadian crown lands. Ongoing colonial dispossession of land and resources resulted in global loss of Indigenous languages and cultural genocide (Royal Commission on Aboriginal Peoples, 1996; Truth and Reconciliation Commission of Canada, 2015) with pervasive structural, institutional, and systemic racism (Reading \& Wien, 2009). Under this directive, First Nations, Métis and Inuit families and communities underwent forcible removal of children and dispossession of traditional lands (Assembly of First Nations, 2018).

Indigenous land and resource dispossession have led to lack of access to traditional foods and medicines (Manuel \& Derrickson, 2017; Norman, 2018). Colonial structural determinants equated with antiIndigenous racism continues to impact Indigenous Peoples with disproportionate illnesses including cardiac, respiratory, diabetes, arthritis, mental health, youth suicide, cancer, and waterborne diseases (Bradford et al., 2016; Indigenous Health Writing Group of the Royal College of Physicians and Surgeons of Canada, 2019). Despite these challenges, Indigenous Peoples are reclaiming language and rights to their waters (United Nations, 2007).
Nurses have a shared responsibility in understanding systemic and structural power dynamics related to water, climate change and health impacts on Indigenous Peoples.

\section{Commodification, Consumption, Contamination}

Water in westernized society is regarded as a commodity and resource for consumption and recreation. Western health and water policies are failing at the municipal, provincial, federal, and worldwide levels (Barlow, 2007; Centre of Indigenous Environmental Resources, 2010; May, 2012). Evidence of poor water quality has raised the alarm on the global health crisis experienced by Indigenous communities without access to safe drinking water and sanitation (Bailie et al., 2007; Bradford et al., 2016 ; Jiménez et al., 2014; Reading et al., 2011; Stephens et al., 2006). This is connected to increasing health disparities in Indigenous populations (Reading \& Wien, 2009) including higher levels of pollution, dams, and poor wastewater management (Gideon MacKay, Cree, personal communication, 2001; Barlow, 2007).

Trillion-dollar water bottling companies are draining ancient aquifers, leaving many Indigenous communities without clean water access (Barlow, 2007). Healthy waterways are impeded by worldviews limited to Western science, corporate control, and individualism (Tom Goldtooth, Lakota/Dene, personal communication, 2006; Huirangi Waikerepuru, Maori, personal communication, 2001). Colonial dominance is further problematic in water improvement projects where meaningful Indigenous community partnerships are neglected (Bradford et al., 2016); the need to recognize Indigenous Peoples' right to free, prior and informed consent is often ignored by corporations and governments (Assembly of First Nations, 2018). Power, control, and greed influence decisions without consent of 
Indigenous Peoples, yet Indigenous Peoples carry a spiritual relationship and responsibility to protect water (Tom Goldtooth, Lakota/Dene, personal communication, 2006; Huirangi Waikerepuru, Maori, personal communication, 2001). Alarmingly, there are few Indigenous contributors to the World Water Forum (World Water Council, 2020) where many decisions are made regarding water with full participation by water bottling corporations that commodify this sacred element.

Many water-dependent ecosystems have diseased fish and game that are no longer safe to consume by Indigenous Peoples for traditional foods and medicines (Gideon MacKay and Sandy Beardy, Cree, personal communication, 2001; Canadian Broadcasting Corporation, 2010; Wikler \& Lameman, 2020; Norman, 2018). The constant harm of waterways is putting humanity's health at risk. Action is needed to address failing Western approaches to water and climate change. Nurses ought to be critically aware and respond to Treaties and local-to-global implementation of UNDRIP, as currently noted in the province of British Columbia (Government of British Columbia, 2020).

\section{Western Knowledge Dominance}

Colonial dispossession of

Indigenous Peoples' lands and resources is further compounded by cultural assimilation and marginalization of Indigenous ways of being, knowing and doing (Manuel \& Derrickson, 2017). If Western science is valued as the sole approach to address climate change, there is an erroneous assumption that Western medicine has exclusive solutions to health challenges. 'Water was our first medicine (Gideon MacKay, Cree, personal communication, 2001). Traditional medicines are being reclaimed by Indigenous Peoples. Nurses ought to self-educate, educate Nursing students on health issues with criticality as lifelong learners (Institute of Medicine, 2011). With this in mind, the Nursing academy and healthcare system is called to be inclusive of human rights that uphold Indigenous traditional teachings to inform responses to climate change, water and health (Simon Lucas, personal communication, 2001; Gideon MacKay, Cree, personal communication; Norman, 2018; Smith \& Sharp, 2012). Indigenous Peoples have much to teach the world about sustainable practices regarding the health of the planet (Elders from Brazil, personal communication, 2018; Mona Polacca, Hopi/Tewa/Havasupai, personal communication, 2010; Norman, 2018; Smith \& Sharp, 2012).

Nurses are called to understand the socio/political/historical determinants of health (Reading \&Wien, 2009) and address the interrelated health inequities experienced by Indigenous Peoples who endure inequitable access to clean water given colonial land and resource dispossession (Sakar et al., 2015). The pervasive impact of colonial oppression and racism of Indigenous Peoples by dominant westernized society presents significant barriers to wellbeing (Allan \& Smylie, 2015). Nurses' obligation to critically examine the historical truths as a means of upholding human rights through cultural safety "predicted on understanding power differentials inherent in health service delivery and redressing these inequities through educational processes" (Kinoshameg et al., 2009, p. 2). We may begin by addressing the issue of extraction by corporations and to support Indigenous leaders and knowledge holders who hold their truth based on their own experiences of their spiritual connectedness and relationship with water, land, and health. The First Nations peoples of North America have a special relationship with water, built on our subsistence ways of life that extends back thousands of years. Our traditional activities depend on water for transportation, for drinking, 
cleaning, purification, and provides habitat for the plants and animals we gather as medicines and foods. Our ability to access good water shapes these traditional activities and our relationships with our surroundings. As Indigenous peoples, First Nations recognize the sacredness of our water, the interconnectedness of all life and the importance of protecting our water from pollution, drought, and waste (Assembly of First Nations, n.d.).

\section{Indigenous Human Rights}

UNDRIP (United Nations, 2007)

Article 25 advocates for Indigenous Peoples' "right to maintain and strengthen their distinctive spiritual relationship with their traditionally owned and otherwise occupied and used lands, territories, waters and coastal seas and other resources and to uphold their responsibilities to future generations in this regard" (p. 19). UNDRIP is fundamental to the recognition of human rights to water, health, lands and territories, culture, language, and spirituality, yet this declaration is not legally enforceable. The future of waterways is often decided by economic and corporate agendas that exclude the voices of Indigenous Peoples (Indigenous Environmental Network, 2020). This gap is further evidenced by parallel water fora platforms at each World Water Forum. Such decisions impact Indigenous Peoples' health and are relevant to our commitment to equity and cultural safety.

\section{Traditional Laws}

Traditional laws or 'Original Instructions' are based on the laws of nature that respect the sacredness and interrelatedness of all beings; they guide Indigenous Peoples to protect, maintain and sustain balance. Some traditional knowledge is sacred to families and cultural groups and is not meant to be shared (Mataatua Declaration on Cultural and Intellectual Property Rights of Indigenous Peoples,
1993). Other values and principles are common knowledge and need to be shared with the wider society as taught over the years by the late Elders Sandy Beardy (Cree), Gideon MacKay (Cree) and Huirangi Waikerepuru (Maori). Such traditional laws are defined in the language (Huirangi Waikerepuru, Maori, personal communication, 2001) and cultural practices. They are "specific to Indigenous peoples... [on] how people govern themselves, and how they solve problems together...people's own law [with] many sources such as custom, songs, stories, language and ceremonies" (West Coast Environmental Law, 2020). Traditional natural laws precede Western state laws and hold the key to protecting the world. While traditional laws are not state/government legislation, Indigenous Peoples have governed their Nations for thousands of years, "actively managing the land and water to sustain their communities and all beings" (West Coast Environmental Law, 2020). Traditional laws are being revitalized as part of global recognition of Indigenous human rights (United Nations, 2007; University of Victoria, 2020).

Traditional knowledge is unique to groups of Indigenous peoples who hold specific knowledge local to their community. Decisions about water often ignore spiritual, moral, and ethical considerations that are fundamental to Indigenous laws and teachings (Tom Goldtooth, Lakota/Dene, personal communication, 2006). Simon Lucas, NuuChah-Nulth Hereditary Chief stated, "if traditional laws about water were recognized and practiced, we wouldn't have a problem with climate change" (personal communication, 2001). Examples of traditional law implementation include a 140-year Maori effort to recognize the Whanganui River as having its own personhood, and is now considered an ancestor by the New Zealand government (New Zealand Parliament, 2017; The Guardian, 2017); in Canada, traditional governance laws of the Secwépemc people 
provide a foundation for protecting water (Ignace \& Ignace, 2017). There is a crucial need for a paradigm shift in our relationship with water (Tom Goldtooth, Lakota/Dene, personal communication, 2008). Over the past two decades, Indigenous peoples have gathered around the world to voice concerns and solutions and create Indigenousinformed water declarations and statements. While these global declarations come from diverse lands and cultures, they share key overlapping themes to Indigenous Peoples' role in water protection and global wellbeing.

\section{Indigenous Water Declarations}

Several Indigenous water declarations have been co-developed with the Indigenous Environmental Network: an alliance of Indigenous Peoples that aims to protect Mother Earth's sacredness “from contamination and exploitation by strengthening, maintaining and respecting Indigenous teachings and natural laws" (2020, para I). The following section summarizes eight of these declarations:

- "Indigenous Declaration on Water" (2001), Musqueam Territory, Canada (Freshwater Future, 2020)

- 'Indigenous Peoples' Kyoto Water Declaration" (2003), Kyoto, Japan (United Nations Educational, Scientific and Cultural Organization, 2006)

- "Declaration of the Peoples World Water Movement" (2004), New Delhi, India

- "Tlatokan Atlahuak Declaration" (2006), Declaration of the Indigenous Peoples Parallel Forum of the 4th World Water Forum, Mexico City, Mexico

- "Water is Sacred, Water is Life, Water is Fundamental: Planning a

World Indigenous Forum on Water and Peace" (2007), New York, USA (6th Session of the United Nations Permanent Forum on Indigenous Issues, 2007)
- "Indigenous World Forum on Water and Peace: Joint Intervention" (2011), New York, USA (10th Session of the United Nations Permanent Forum on Indigenous Issues, 2011)

Three overarching key themes were noted: Indigenous worldviews support water and global wellbeing, water is in crisis, and water ought to be informed and protected by traditional law.

\section{Indigenous Worldviews Support Water and Global Wellbeing}

Water is Mother Earth's most sacred resource and Indigenous Peoples' relationship with Mother Earth comes with responsibility to conserve and protect water for future generations. Indigenous Peoples have a sacred responsibility to care for water as the physical, spiritual, cultural basis for existence. Water is Indigenous Peoples' first medicine that cleanses and heals, physically and spiritually. Water teaches humility, how to live an exemplary life, how to care and to be responsible. These Indigenous values are foundational principles that guide discourse on global water ethics (Groenfeldt, 2014; Norman, 2018). In the face of devastating climate changes, such as escalating fires and flooding, the implementation of Indigenous traditional laws may be our best opportunity going forward.

\section{Water is in Crisis}

Indigenous Peoples depend upon waterways that are threatened by pollution with chemicals, pesticides, heavy metals, radioactive materials, agricultural runoff, and sewage that cause disease to humans, plants, and animals. Ongoing nuclear waste, leakages, mining, and mineral extraction, dumping from mines and contaminated sites, erosion from dams, river diversions, economic development, fracking, forestry, water commodification, fossil fuel extraction, and thermal contamination all contribute to this crisis. This damage to waterways has destroyed whole ecosystems and exacerbated climate change 
(Intergovernmental Panel on Climate

Change, 2019; Lameman, 2020).

\section{Water can be Protected}

The reinforcement of traditional laws will protect water with local Indigenous traditions and environmental governance systems. Indigenous peoples have key roles in water protection: women as water keepers, Elders and knowledge holders with ancient stories and songs, and Indigenous youth as future leaders. Traditional laws are a foundation to developing processes and policies to hold governments, international financial institutions (such as the World Bank), and multinational corporations accountable for water conservation and protection.

\section{Nursing Response: Indigenous Worldviews, Crisis \& Opportunity}

Nurses may respond to each theme in the realms of advocacy, education, research, community capacity-building and development, and by supporting Indigenous led-research. Indigenous and nonIndigenous nurses alike have a role in ensuring the protection and promotion of Indigenous Peoples' health and human rights. It is important for nurses to be involved with public policy for access to clean water and endorsement of Treaty Rights as Indigenous Peoples' fundamental right to self-determination. Central to our progress is ratifying beliefs to understand core unresolved issues about the land and how economic powers are determining the political agenda.

\section{Nursing, Water, and Indigenous Worldviews}

What is our role in understanding Indigenous worldviews related to health, water, and climate change? For millennia, Indigenous traditional teachings have guided water protection and prophesied climate change; yet, Nursing education and practice often marginalizes Indigenous ways of being, knowing and doing. As part of our decolonizing and reconciliation efforts, nurses are encouraged to practice cultural humility (First Nations Health Authority, 2020).

Cree scholar and traditional

knowledge holder Willie Ermine (2007) speaks to respectful dialogue within an "ethical space" where different cultures can relate. We advocate for a rights-based approach that elevates Indigenous laws, values and practices to protect water while engaging with Western science (Lavalley, 2006; McGregor et al., 2018; Sandford \& Phare, 2011; Stefanelli et al., 2017; Walkem, 2007). Modern water policy can embrace traditional water laws and UNDRIP. This also reveals possibilities for all peoples to work in unity and protect water and promote health. Nurses can advance this approach by advocating for Indigenous traditional knowledge to be part of education and healthcare.

\section{Nursing and the Water Crisis}

What is our role in maintaining planetary health and access to clean water? Related global health priorities are confirmed in the "Sustainable Development Goals" by the United Nations (2020), including Goal 6: Clean Water and Sanitation, Goal 7: Affordable and Clean Energy, and Goal 10: Reduced Inequalities. Indigenous Peoples' lack of clean water access is a global health crisis (Bradford et al., 2016; Sakar et al., 2015; Stefanelli et al., 2017). Nurses have the collective capacity for complex thinking and systems level action to address this issue at a local-toglobal levels. According to the International Council of Nurses (2018), actions include:

- developing climateinformed health programmes.

- engaging in sustainable practices in the health sector. 
See it. Speak it. Write it. Change it.

- building the response capacity of the health workforce.

- engaging in health and climate research.

- participating in intersectoral policy and governance responses (p. 2).

\section{Nursing Opportunities and Indigenous Water Protection}

What is Nursing's role in supporting traditional laws and participation in water protection? Nurses have a responsibility to make space for Indigenous voices and critically appraise current policies and practices to reveal structural barriers that impede our abilities to see water as a living being. Water and land are wrongly viewed as resources to be exploited; consumerism and corporatization contribute to depleting water and harming the natural world (Tom Goldtooth, Lakota/Dene, personal communication, 2008). Western laws and policies are incomplete to protect water. From a unifying perspective, promising integrative Indigenous-Western approaches in Canada, Australia, New Zealand and the United States may help us to remedy water protection by showing us how "living in harmony" with worldviews (Stefanelli et al., 2017). Nurses are called to:

1. understand their own identity and know where their ancestors originate from.

2. recognize that the land where they are situated is Indigenous lands and waterways.

3. critically examine their own levels of eco-literacy and how it intersects interculturally in developing current practices standards; and

4. identify local/regional/international barriers to clean water.

It is important for nurses to understand where the water source is, and whether it is protected. As Peter O'Chiese (Cree) stated, "protect the source" (personal communication, 1999).

\section{Opportunity and Responsibility}

What is Nursing's role in

reconciling water and health?

Interconnections of health, water, and

climate change are aligned with Nursing

position statements (Canadian Nurses

Association, 2017; International Council of Nurses, 2018). Rarotonga Hereditary Chief TeTika Mataiapo's teachings about water's interconnectedness (personal communication, 2008) help us to understand how water is a unifying force. Nurses are called to respect the connection of water to health for Indigenous Peoples, the importance of spirituality in healing practices, and to create space for such practices. Provisions should be made by nurses for Indigenous clients to be on the land and visit waterways as part of their healing journey. Indigenous Health Nursing leadership opportunities will expand Nursing knowledge, human rights, and planetary health by addressing climate change in education, practice, research, and policy development. These strategies will address many gaps in securing a healthy future for our common waterways. Local Indigenous Elders and knowledge holders need to be invited to share stories about water and waterways on the lands where the college/university is situated. Mutually beneficial relationships and partnerships may be built to develop curriculum on water and health. This can facilitate learning about water governance and policy development that upholds Indigenous traditional knowledge and practices. Researchers can further expand evidence by facilitating Indigenous-led Indigenous research methodologies to examine traditional approaches to water and climate change. An example of this research program was developed by the "Secwépemc Water Guardians" summer student program, supported by the SSHRC connections grant (Tk'emlúps te Secwépemc, 2019). Such community engagement supports Indigenous self-determination through language 
revitalization, cultural practices, and water decision-making.

\section{Social Justice and Indigenous Self- Determination}

Grass roots efforts by Indigenous non-government organizations, such as the Indigenous Environmental Network, have taken a strong stand for many years to uphold traditional knowledge for addressing climate change issues. Since 1999, a global working group of Indigenous leaders, Elders, and knowledge holders (including Sanderson and Polacca) advocated for the Indigenous World Forum on Water and Peace with the United Nations Permanent Forum on Indigenous Issues (2006-2011). This group also proposed the Global Indigenous Observatory on Water and Peace at the World Water Forum in (2018) for Indigenous Peoples to use cultural indicators for monitoring their waterways.

Nurses may support these initiatives since "nursing is a political act" (Canadian Nurses Association, 2009, p.1). We all have a role to play in engaging in Indigenousinformed water innovations and shaping related health policy across all domains of Nursing practice. This requires collaboration with nurses, interdisciplinary professionals, and Indigenous Peoples to advance health and "living in harmony" for the greater good.

Nurses' code of ethics calls for social justice (International Council of Nurses, 2012) as the "fair distribution of resource and responsibilities" (Canadian Nurses Association, 2009, p. 2). Indigenous Peoples have the right to equal opportunity and inclusion of traditional ways of being, knowing and doing in dominant westernized society. Indigenous self-determination is well defined by UNDRIP as the right for Indigenous Peoples to make decisions affecting their waterways. Selfdetermination pertaining to health is ensured by Indigenous Peoples' designing, delivering, and evaluating their health priorities and programs. Nurses can support self-determination in Indigenous communities by:

- Advocating for implementation of the UNDRIP at all levels of government, noting articles on free, prior, and informed consent.

- Upholding the Declaration on the Rights of Mother Earth (World Peoples' Conference on Climate Change and the Rights of Mother Earth, 2011) which recognizes the Earth as a living entity and Indigenous Peoples' rights and responsibilities.

- Recognizing the right of Indigenous Peoples to protest extractive projects negatively impacting waterways and exacerbating climate change.

- Supporting Indigenous governments and jurisdictions to develop state legislation to protect water reflecting Indigenous laws.

By supporting self-determination, nurses can play a key role in supporting Indigenous Peoples to enact their own solutions for health and wellbeing.

\section{Conclusion}

This discussion is a catalyst to extend dialogue on the role of nurses with Indigenous Peoples' health, water, and climate change. Rarotonga Hereditary Chief, TeTika Mataiapo, stated that "water connects us all" (personal communication, 2001). Nurses have an opportunity and responsibility to reconcile the lack of clean water access by Indigenous Peoples and marginalization of Indigenous ways of knowing which supports relational water responsibility. Indigenous Peoples' rights need to be respected and implemented (United Nations, 2007). If Indigenous and non-Indigenous nurses alike engage in Indigenous Health Nursing actions that uphold Indigenous Rights, a renewed understanding of sustainable water 
infrastructure may advance health policy. Through traditional Indigenous laws about water and Indigenous-informed strategies to address climate change, we may look to a healthy future for everyone. Elders shared with us: "It is through the remembering of our past that we find keys to the future"; and, "the answer lies within".

\section{References}

6th Session of the United Nations Permanent Forum on Indigenous Peoples Issues. (2007). Water is sacred, water is life, water is fundamental: planning a world Indigenous forum on water and peace. Requesting support and participation of the UNPFII. http://cendoc.docip.org/collect/cendo cdo/index/assoc/HASH0ea5/02c6ebb 0.dir/PF07darlene270.pdf

10th Session of the United Nations Permanent Forum on Indigenous Peoples Issues. (2011). Indigenous world forum on water and peace: Joint intervention. http://cendoc.docip.org/collect/cendo cdo/index/assoc/HASH5538/77eab4c 2.dir/PFIIdarlene274.pdf\#search $=\% 2$ 2sanderson $\% 22$

Allan, B. \& Smylie, J. (2015). First Peoples, second class treatment: The role of racism in the health and well-being of Indigenous peoples in Canada. Toronto, ON: Wellesley Institute.

Anderson, K., Clow, B., \& HaworthBrockman, M. (2013). Carriers of water: Aboriginal women's experiences, relationships and reflections. Journal of Cleaner Production, 60(1), 11-17.

Assembly of First Nations. (2018).

Dismantling the doctrine of discovery. https://www.afn.ca/wpcontent/uploads/2018/02/18-01-22Dismantling-the-Doctrine-ofDiscovery-EN.pdf

Assembly of First Nations. (n.d.). Honoring water. https://www.afn.ca/honoringwater/
Astle, B., Bourque Bearskin, R.L., Dordunno, D., Egert, A., Houweling, R., Moen, N., Plamondon, K., Radu, R., Sanderson, D., \& Smith, C. (2020). Nurses for planetary health: a call to action. Nurses and Nurse Practitioners of British Columbia. https://www.nnpbc.com/nurses-forplanetary-health-a-call-toaction/\# ftn1

Bailie, R. S., Carson, B. E., \& McDonald, E. L. (2007). Water supply and sanitation in remote Indigenous communities - priorities for health development. Australian and New Zealand Journal of Public Health, 28(5). https://doi.org/10.1111/j.1467842X.2004.tb00021.X

Barlow, M. (2007). Our water commons: toward a new freshwater narrative. Ottawa, ON: The Council of Canadians. https://www.deslibris.ca/ID/216046

Bradford, L. E., Okpalauwaekwe, U., Waldner, C. L., \& Bharadwaj, L. A. (2016). Drinking water quality in Indigenous communities in Canada and health outcomes: a scoping review. International Journal of Circumpolar Health, 75, 1-16. https://doi.org/10.3402/ijch.v75.3233 6

Canadian Broadcasting Corporation. (Sept 16, 2010). Oilsands poisoning fish, say scientists, fishermen.

https://www.cbc.ca/news/canada/ed monton/oilsands-poisoning-fish-sayscientists-fishermen-1.939507

Canadian Nurses Association. (2017). Climate change and health. Ottawa, ON: Author. https://www.cnaaiic.ca/-/media/cna/pagecontent/pdf-en/climate-change-andhealth-position-statement.pdf

Canadian Nurses Association. (2009). Social justice in practice. Ottawa, ON:

Author. https://www.cnaaiic.ca/ /media/cna/pagecontent/pdfen/ethics_in practice_april_2009 e. pdf?la $=$ en 
Canadian Public Health Association. (2019). Climate change and human health. https://cpha.ca/climate-change-andhuman-health

Carling, A. \& Manjani, I. (2020). Systemic inequities increase COVID-19 risk for Indigenous people in Canada: Challenges include barriers to healthcare, adequate housing and resources. Human Rights Watch. https://www.hrw.org/news/2020/06/ 09/systemic-inequities-increasecovid-19-risk-indigenous-peoplecanada

Centre of Indigenous Environmental Resources. (September 15, 2010). First Nations water security and climate change: Workshop report. https://www.psf.ca/sites/default/files /FN H2O CC Wkshp RptFINAL. pdf

Costello, A., Abbas, M., Allen, A., Ball, S., Bell, S., Bellamy, R., Friel, S., Groce, N., Johnson, A., Kett, M., Lee, M., Levy, C., Maslin, M., McCoy, D., McGuire, B., Montgomery, H., Napier, D., Pagel, C., Patel, J., ...Patterson, C. (2009). Managing the health effects of climate change. The Lancet ,373(9676), 1693-1733.

Declaration of the Peoples World Water Movement. (2004). Declaration of the Peoples World Water Movement. New Delhi, India January 2004. https://contrattoacqua.it/public/uplo ad/1/2/tab elms docs/1327829213f orum-4 declaration-new-dehli.pdf

Deloria, V. (1999). Spirit and reason. B. Deloria, K. Foehner \& S. Scinta (Eds.). Golden, CO: Fulcrum Publishing.

Ermine, W. (2006). The ethical space of engagement. Indigenous Law Journal, 6(1). 194-203.

First Nations Health Authority. (2020). Cultural humility. https://www.fnha.ca/wellness/cultur al-humility
Freshwater Future. (2020). Indigenous declaration on water. https://freshwaterfuture.org/commu nityresources/publications/freshwatervoices-newsletter-archive/volume10-number-4-\%E2\%80\%A2-fall2002/indigenous-declaration-onwater/

Government of British Columbia. (2020). A new path forward. https://declaration.gov.bc.ca

Government of Canada. (2020a). Ending long-term drinking water advisories. https://www.sacisc.gc.ca/eng/1506514143353/15333 17130660

Government of Canada. (2020b). Long-term advisories affecting water systems not financially supported by the government of Canada south of 60 . https://www.sacisc.gc.ca/eng/1516134315897/15336 63683531

Groenfeldt, D. (2014). Water ethics: A values approach to solving the water crisis. Water Resources Management: An International Journal, 28(6), 1481-1483.

Ignace, R., \& Ignace, M. (2017). Secwépemc people, land and laws. Montreal, QC \& Kingston, ON: McGillQueen's University Press.

Indigenous Environmental Network. (2020). Indigenous Environmental Network. https://www.ienearth.org/

Indigenous Peoples of the Americas. (n.d.). Message from Indigenous people from America, from La Cocha, Guamuès, Pasto, Nariño. https://sierranevada.wordpress.com/ 2009/09/03/mensaje-de-los-pueblosoriginarios-de-america-desde-lacocha-guamues-pasto-narino/

Indigenous Health Writing Group of the Royal College of Physicians and Surgeons of Canada. (2019). Indigenous health primer. Ottawa, ON: Royal College of Physicians and Surgeons of Canada. http://www.royalcollege.ca/rcsite/he 
The Canadian Journal of Critical Nursing Discourse

See it. Speak it. Write it. Change it.

alth-policy/initiatives/indigenoushealth-e

Institute of Medicine. (2011). The future of nursing: leading change, advancing health. Washington, CD: The National Academies Press. https://doi.org/10.17226/12956

Intergovernmental Panel on Climate Change. (2019). AR6 climate change 2021: impacts, adaptation and vulnerability, the working group II contribution to the sixth assessment report. https://www.ipcc.ch/report/sixthassessment-report-working-group-ii/

International Council of Nurses. (2012). The ICN code of ethics for nurses. Geneva, Switzerland: Author. https://www.icn.ch/sites/default/files /inline-

files/2012 ICN Codeofethicsfornur ses \%20eng.pdf

International Council of Nurses. (2018). Nurses, climate change and health. Geneva, Switzerland: Author. https://www.icn.ch/sites/default/files /inline-

files/PS E Nurses climate\%20chan ge health 0.pdf

Jiménez, A., Cortobius, M., \& Kjellén, M. (2014). Water, sanitation and hygiene and Indigenous peoples: a review of the literature, Water International, 39(3), 277-293, DOI: $10.1080 / 02508060.2014 .903453$

Kinoshameg, R. M., Rukholm, E., \& Villeneuve, M. (2009). Cultural competence and cultural safety in nursing education: A framework for First Nations, Inuit and Métis Nursing. Aboriginal Nurses Association of Canada. https://www.cnaaiic.ca/ /media/cna/pagecontent/pdfen/first_nations framework_e.pdf

Kogi People. (1992). From the heart of the world: The elder brothers' warning - Kogi message to humanity. https://www.youtube.com/watch?v= hRgTtrQOiR0
Lameman, C. (June 2020). Reconcile this: health, wellness and safety during a world pandemic, or concessions for extreme resource extraction. https://raventrust.com/2020/05/25/re concile-this-health-wellness-andsafety-during-a-world-pandemic-orconcessions-for-extreme-resourceextraction/

Lavalley, G. (2006). Aboriginal traditional knowledge and source water protection: First Nations' views on taking care of water. Toronto, Canada: Chiefs of Ontario.

Mandamin. J. (n.d.). Nokomis Josephine Mandamin - Anishinaabe waterwalker, Elder, teacher \& leader. https://www.youtube.com/watch?v= $\underline{\text { slkFBxqGd4U }}$

Manuel, A. (2017). From dispossession to dependency. In P. MacFarlane, and N. Schabus, (Eds). Whose land is it anyway? (pp 18-21). Vancouver, BC: Federation of Postsecondary Educators of BC. http://www.fpse.ca/sites/default/files /news files/Decolonization $\% 20 \mathrm{Han}$ dbook.pdf

Manuel, A., \& Derrickson, R. (2017). The reconciliation manifesto recovering the land and rebuilding the economy. Toronto, ON: Lorimer and Company Ltd.

Marshall, M., Marshall, A. \&; Bartlett, C. (2015). Two-eyed seeing in medicine. In M. Greenwood, S. de Leeuw and C. Reading (Eds.) Determinants of Indigenous peoples' health in Canada. Beyond the social (pp. 16-24). Toronto, ON: Canadian Scholars' Press.

Mataatua Declaration on Cultural and Intellectual Property Rights of Indigenous Peoples. (June 1993). First International Conference on the cultural \& intellectual property rights of Indigenous peoples. Whakatane: 12-18. Aotearoa, New Zealand. http://www.ankn.uaf.edu/IKS/mataa tua.html 
Martin, W. \& Vold, L. (2019). Climate change and health. It is time for nurses to act. A discussion paper. Ottawa, ON: Canadian Federation of Nurses Unions.

https://nursesunions.ca/wpcontent/uploads/2019/05/CFNU clim atechange-web.pdf

May, E. (May 10, 2012). Bill C-38: The environmental destruction act. The Tyee. https://thetyee.ca/Opinion/2012/05/1 0/Bill-C38/

McGregor D., Arsenault, R., Wilson, N. (November 15, 2018). Community based research methods in water planning and governance with First Nations. Canadian Water Network. http://cwn-rce.ca/wpcontent/uploads/11-15-2018CWNSYP-Engaging-CommunityBased-Research-Methods-in-WaterPlanning-and-Governance-withFirst-Nations.pdf

Miller, R.J. (2015). The doctrine of discovery, manifest destiny, and American Indians. Why you can't teach United States history without American Indians. [Unpublished manuscript]. Tempe, AZ: Arizona State University. https://papers.ssrn.com/sol3/papers. cfm?abstract id $=2689279$

New Zealand Parliament. (March 28, 2017). Innovative bill protects Whanganui River with legal personhood. https://www.parliament.nz/en/getinvolved/features/innovative-billprotects-whanganui-river-withlegal-personhood/

Norman, E. S. (2018). Toward a global water ethic: learning from Indigenous communities. Ethics \& International Affairs, 32(2), 237-247. https://doi.org/10.1017/S0892679418 000333

Office of the United Nations High Commissioner for Human Rights and World Health Organization (2008). The right to health. Fact sheet no. 31 . Geneva: Author.
https://www.ohchr.org/Documents/Pu blications/Factsheet31.pdf

Reading, J., Peron, D., Marsden, N., Edgar, R., Saravana-Bowen, B., \& Baba, L. (Eds.) (2011). Crisis on tap: Seeking solutions for safe water for Indigenous peoples. https://www.uvic.ca/research/centre s/circle/assets/docs/Publications/cris is-on-tap-cahr.pdf

Reading, C.L., \& Wien, F. (2009). Health inequalities and the social determinants of Aboriginal peoples' health. Prince George, BC: National Collaborating Centre for Aboriginal Health.

Robbins, J. A., \& Dewar, J. (2011). Traditional Indigenous approaches to healing and the modern welfare of traditional knowledge, spirituality and lands: A critical reflection on practices and policies taken from the Canadian Indigenous example. The International Indigenous Policy Journal, 2(4), 1- 20. https://doi.org/10.18584/iipj.2011.2.4. $\underline{2}$

Royal College of Physicians and Surgeons. (2012). Disparities in health outcomes and inequities in the quality of health care services for Aboriginal peoples. http://www.royalcollege.ca/rcsite/doc uments/health-policy/indigenoushealth-discussion-paper-e.pdf

Royal Commission on Aboriginal Peoples. (1996). People to people, nation to nation: Highlights from the report of the Royal Commission on Aboriginal Peoples. Ottawa, ON: Minister of Supply and Services.

Sanderson, C. (2008). Nipiy wasekimew/clear water: The meaning of water from the words of the Elders: The interconnections of health, education, law, and the environment. [Doctoral dissertation]. Burnaby, BC: Simon Fraser University.

Sandford, R., \& Phare, M. (2011). Ethical water: Learning to value what 
matters most. Victoria, BC: Rocky Mountain Books.

Sarkar, A., Hanrahan, M., \& Hudson, A. (2015). Water insecurity in Canadian Indigenous communities: some inconvenient truths. Rural and Remote Health, 15(4), 1-13. www.rrh.org.au/journal/article/3354

Smith, H. A., \& Sharp, K. (2012). Indigenous climate knowledges. WIREs Climate Change, 3(5), 467476. https://doi.org/10.1002/wcc.185

Smith, L. (1999). Decolonizing methodologies: Research and Indigenous peoples. Dunedin, NZ: University of Otago Press.

Stefanelli, R.D., Castleden, H., Harper, S.L., Martin, D., Cunsolo, A., \& Hart, C. (2017). Experiences with integrative Indigenous and Western knowledge in water research and management: a systematic realist review of literature from Canada, Australia, New Zealand, and the United States. Environmental Reviews, 25(3), 323333.

https://www.nrcresearchpress.com/doi /10.1139/er-2016-0114

Stephens, C., Porter, J., Nettleton, C., \& Willis, R. (2006). Disappearing, displaced, and undervalued: a call to action for Indigenous health worldwide. Lancet, 367, 2019-2028.

The Guardian. (2017). New Zealand river granted same rights as human beings.

https://www.theguardian.com/world /2017/mar/16/new-zealand-rivergranted-same-legal-rights-ashuman-being

Tlatokan Atlahuak Declaration. (2006). Declaration of the Indigenous Peoples Parallel Forum of the 4th World Water Forum. http://media.knet.ca/node/1952

Tk'emlúps te Secwépemc (Summer 2019). Tk'emlúps te Secwépemc Summer Lexéy'em. https://tkemlups.ca/files/2019/09/2019 -Summer-Lexeyem-web-1.pdf
Truth and Reconciliation Commission of Canada. (2015). Honouring the truth, reconciling for the future. Summary of the final report of the Truth and Reconciliation Commission of Canada. Winnipeg, MB: Author. http://www.trc.ca/assets/pdf/Honourin $\mathrm{g}$ the Truth Reconciling for the Fu ture July_23_2015.pdf

United Nations Educational, Scientific and Cultural Organization. (2006). Indigenous Peoples Kyoto Water Declaration. Third World Water Forum, Kyoto, Japan. March 2003. Water and Indigenous Peoples. https://unesdoc.unesco.org/ark:/48223 /pf0000145353

United Nations Children's Fund. (2019). Water under fire. New York, NY: United Nations Children's Fund (UNICEF) and World Health Organization.

https://www.unicef.org/reports/wate r-under-fire-2019

United Nations. (2020). Sustainable development goals. New York, NY: Author. https://www.un.org/sustainabledevelo pment/sustainable-developmentgoals/

United Nations. (2015). Paris Agreement. New York, NY: Author. https://unfccc.int/sites/default/files/en glish paris agreement.pdf

United Nations. (2010). Human rights to water and sanitation. New York, NY: Author. https://www.unwater.org/waterfacts/human-rights/

United Nations. (2007). United Nations Declaration on the Rights of Indigenous Peoples. New York, NY: Author. https://www.un.org/development/desa /indigenouspeoples/declaration-onthe-rights-of-indigenous-peoples.html

University of Victoria. (2020). Indigenous law research unit (ILRU). https://www.uvic.ca/law/about/indige nous/indigenouslawresearchunit/ 
The Canadian Journal of Critical Nursing Discourse

See it. Speak it. Write it. Change it.

Walkem, A. (2007). The land is dry: Indigenous Peoples, water, and environmental justice. In Karen Bakker (Ed.), Eau Canada: The future of Canada's water, (303 319). Vancouver, BC: UBC Press.

West Coast Environmental Law. (2020). Indigenous law.

https://www.wcel.org/program/indige nous-law

Wikler, M., \& Lameman, C. (June 5, 2020). Beaver Lake Cree stands strong as Canada and Alberta attempt to derail tarsands legal challenge. Briarpatch Magazine. https://briarpatchmagazine.com/article s/view/beaver-lake-cree-stand-strongas-canada-and-alberta-attempt-toderail-tarsands-legal-challenge

World Health Organization (2017). 2.1 billion people lack safe drinking water at home, more than twice as many lack safe sanitation. Geneva: Author. https://www.who.int/newsroom/detail/12-07-2017-2-1-billionpeople-lack-safe-drinking-water-athome-more-than-twice-as-many-lacksafe-sanitation

World Peoples' Conference on Climate Change and the Rights of Mother Earth. (2011). Building the peoples' movement for mother earth: Rights of mother earth.

https://pwccc.wordpress.com/progra ma/

World Water Council. (2020). 9th World Water Forum, Dakar 2021, water security for peace and development. https://www.worldwatercouncil.org/ $\underline{\text { en/dakar-2021 }}$ 